\title{
GENETIC CHARACTERIZATION OF SWAMP EEL OF BANGLADESH THROUGH DNA BARCODING AND RAPD TECHNIQUES
}

\author{
MD MINHAZUL ABEDIN, MD MOSTAVI ENAN ESHIK, NUSRAT JAHAN \\ PUNOM, MST. KHADIZA BEGUM AND MOHAMMAD SHAMSUR RAHMAN* \\ Department of Fisheries, University of Dhaka, Dhaka 1000, Bangladesh
}

\begin{abstract}
The freshwater air-breathing swamp eel Monopterus spp. are native to the freshwater of Bangladesh and throughout the Indian subcontinent. To identify the different swamp eel species and to check the genetic diversity among them, a total of twelve swamp eel specimens were collected from four districts (Tangail, Bogura, Bagerhat and Sylhet) representing the four division of Bangladesh. The extracted DNA from twelve fish samples was amplified by the PCR technique for DNA barcoding and RAPD analysis. Among 12 specimens, 8 specimens showed a 95-100\% similarity with $M$. cuchia species published in the NCBI GenBank database and BOLD system. The studied met3 (collected from Tangail region), mcs1, mcs2 and mcs3 (collected from Sylhet region) specimens showed about 83\% homology with Ophisternon sp. MFIV306-10 as per BLAST search; whereas BOLD private database showed $99 \%$ similarity with Ophisternon bengalense (Bengal eel). From the phylogenetic tree analysis, 8 samples were clustered with $M$. cuchia and 4 samples showed similarity with Ophisternon sp. MFIV306-10 and Ophisternon bengalense _ANGBF45828-19. In RAPD-PCR based analysis, it was found that the maximum genetic distance (1.6094) was observed between mcba 2 and mcs 3 , while between mct 1 and mct 2 , the minimum genetic distance was 0.000 . A total of 192 bands, of which 35 were polymorphic with $17.88 \%$ polymorphisms among swamp eel species and the size of the amplified DNA fragments ranged from 250 to $1800 \mathrm{bp}$. The information on DNA barcoding and RAPD analysis help measure the genetic diversity among swamp eel species, ensure the reliability of the published taxonomic information, and initiate proper management programs to conserve these vulnerable species to meet future export demand.
\end{abstract}

Key words: DNA barcoding, RAPD, Monopterus spp., Ophisternon spp.

\section{Introduction}

The freshwater air-breathing swamp/mud eel Monopterus spp. belong to the family synbranchidae of the order synbranchiformes (Rosen and Greenwood 1976, Shafi and Quddus 1982). It commonly inhabits in the freshwater of Bangladesh and throughout India (Talwar and Jhingran 1991). The freshwater mud eel, Monopterus cuchia is a delicious, tasty, nutritional and economically valuable fish. In Bangladesh, only the tribal

*Corresponding author: <shamsur@du.ac.bd>. 
people consume this fish but nowadays, it is a commercially exportable product because of its high demand worldwide (Begum et al. 2018). These hardy, pollution resistant species are carnivorous, nocturnal and like animal-based foods, such as small fishes, mollusks and worms (Nasar 1997). This species can also adapt to various adverse situations like low oxygen concentration, high temperature and shallow water (Rahman 2005). Ophisternon spp. is known as swamp eel belongs to the family of synbranchidae. Species of this family can breathe in the air, making them capable of surviving in lowoxygenated water and moving between ponds during the rainy season. Swamp eels are naturally distributed throughout India, Sri Lanka, Indonesia, Philippines and New Guinea (Roy et al. 2016). Monopterus are exported every year from Bangladesh to different countries like China, Japan, South Korea, Malaysia, Hong Kong, Thailand, Europe and earn 14 million US dollar in 2014 (DoF 2016). It is now over exploited from the natural water-bodies mainly for being exported (Begum et al. 2018). The swamp eel viz. M. cuchia and $O$. bengalense have been enlisted in the red list of threatened fishes of Bangladesh as a vulnerable (IUCN 2015). Therefore, it is very much important to identify the fish species accurately and unambiguously for conservation purposes. Genetic data are very important in assessing the gene flow between populations, which are also critical for maintaining genetic diversity. DNA based technologies have been recognized useful for their application in species identification (Palumbi and Cipriano 1998), monitoring fisheries (Menezes et al. 2006) and aquaculture (Liu et al. 1998). Genetic data can also be interpreted in such a way to set up conservation priorities. In many instances, genetics may be the best way to decide whether the species need conservation actions under the vulnerable category. Genetic data of threatened species can help to decide restocking of the species through translocation (Teske et al. 2003) by implementing a planned program based on quantitative genetics, life history data and DNA variation (Epifanio 2003). DNA barcoding is an identification tool in which a small fragment of mitochondrial genome acts as a 'DNA barcode' to identity an organism at its species level. DNA barcoding is suitable because the intra-species variations are lesser than inter-species variations (Peninal et al. 2017). DNA barcoding has the advantage of identifying the species from any sort of sample like whole fish, fillets, fins, juveniles, larvae, eggs, or tissue fragments. DNA barcoding can be a practical tool for the reliable identification of specimens for solving taxonomic problems and providing an in-depth analysis of gene flow (Smith et al. 2008).

Among DNA based systems, the RAPD-PCR procedure is simple and fast. Without prior information on DNA arrangements, it is conceivable to distinguish hereditary variety utilizing RAPD strategy. The technique, also known as arbitrary primer-polymerase chain 
reaction (AP-PCR), has been widely used for revealing the intraspecific variation (Basagoudanavar et al. 1998). We studied the genetic diversity and relationship among the swamp eel specimens collected from the four natural habitats of Bangladesh (Tangail, Bagerhat, Bogura and Sylhet). The present study was aimed at the molecular identification and characterization of swamp eel species lives in the natural water bodies of different regions of Bangladesh based on DNA barcoding and RAPD techniques.

\section{Materials and Methods}

Twelve specimens of swamp eel were collected from four districts representing four divisions of Bangladesh viz., Bogura of Rajshahi division, Tangail of Dhaka division, Sylhet of Sylhet division, Bagerhat of Khulna division and were subjected to molecular study. Fishes were examined while still fresh. Total length (TL) and weight were measured. The primary identification was made according to Shafi and Quddus (1982) and Talwar and Jhingran (1991).

Fresh muscle samples were collected and preserved at $-20^{\circ} \mathrm{C}$. DNA from the muscle of 12 swamp eel specimens was extracted using a commercial kit (Maxwell 16 MDx Research Instrument, Promega, USA) according to manufacturer's instruction. The absorbance of purified DNA by NanoDrop spectrophotometer (Thermo Fisher Scientific Inc., USA) was checked at $260 \mathrm{~nm}$. Extracted DNA used as a template for PCR amplification of a $650 \mathrm{bp}$ fragment from the $5^{\prime}$ region of COI gene using the forward and reverse primer FishF1 (TCAACCAACCACAAAGACATTGGCAC) and FishR1 (TAGACTTCTGGGTGGCC AAAGAATCA) (Ward et al. 2005) and the PCR reaction mix for $25 \mu$ l contained GoTaq ${ }^{\circledR}$ G2 Hot Start Green Master Mix, $2 X 12.5 \mu \mathrm{L}$, forward primer $1 \mu$, reverse primer $1 \mu \mathrm{l}$, DNA template $1 \mu \mathrm{l}$, nuclease free water $9.5 \mu \mathrm{l}$ and thermal cycling conditions were followed as reported by Wong and Hanner (2008). Amplified DNA was then purified using Wizard PCR SV Gel and PCR Clean-Up System kit (Promega, USA) prior to sequencing. Sequencing of purified PCR products was performed through commercial service of the First Base laboratory, Malaysia.

COI sequences were identified by searching the GenBank database using the BLASTN algorithm (https://blast.ncbi.nlm.nih.gov) and by BOLD (http://www.boldsystems.org) identification engine to search DNA barcode records within BOLD (Ratnasingham and Herbert 2007). A Neighbor-Joining method (Saitou and Nei 1987) was used to generate tree in MEGA X (Kumar et al. 2018) software to observe the phylogeny among the studied specimens. 
Among 10 primers tested for RAPD amplification, six primers [Operon Technologies Inc., USA (5) and University of British Columbia, Canada (1)] named OPA12 (TCGGCGATAG), OPC5 (GATGACCGCC), OPH4 (GGAAGTCGCC), OPG3 (AGTCGGCCCA), OPY7 (AGAGCCGTCA) and UBC4 (CCTGGGCTGG) exhibited good quality banding patterns and sufficient visibility. The bands of these six primers were further considered for the final RAPD analysis.

The PCR reaction mix for $25 \mu \mathrm{l}$ contained Nuclease-Free Water 14, GoTaq ${ }^{\circledR}$ G2 Hot Start Green Master Mix 2X $7.5 \mu \mathrm{l}$, primer, $10 \mu \mathrm{M} 1.5 \mu$, template DNA $2 \mu \mathrm{l}$. PCR amplification was done in an oil-free thermal cycle for 40 cycles after initial denaturation at $95^{\circ} \mathrm{C}$ for $5 \mathrm{~min}$, denaturation at $95^{\circ} \mathrm{C}$ for $30 \mathrm{~s}$, annealing at $34^{\circ} \mathrm{C}$ for $30 \mathrm{~s}$, extension at $72^{\circ} \mathrm{C}$ for $1 \mathrm{~min}$ and a final extension at $72^{\circ} \mathrm{C}$ for $5 \mathrm{~min}$.

DNA bands were observed on UV-trans illuminator and photographed by a gel documentation system, after $1 \%$ agarose gel electrophoresis. The photographs were critically analyzed on the basis of presence (score 1) or absence (score 0 ) of the band, band size and overall polymorphisms of the bands (Kabir et al. 2017). The value of pairwise genetic distances was analyzed by using computer software "POPGENE 32" (version 1.31) among studied specimens of swamp eel of four geographically different regions from the data of six RAPD primers.

\section{Results and Discussion}

A total of twelve samples were collected from four different regions of Bangladesh, and the total length (TL) and the weight of the fish samples were measured (Table 1).

The extracted DNA from twelve fish samples was amplified by the PCR technique for Cytochrome c Oxidase subunit 1 (COI) gene through COI specific primers FishF1 and FishR1. All the samples showed a positive band at 650 bp (Fig 1).

The resulting PCR products were sequenced to generate full-length DNA barcodes of 678 bp in length, with no detectable insertions, deletions. Table 2 provides information about viz. maximum score, percentage of query coverage, E value, percentage identity, NCBI GenBank accession number, BOLD accession number of the matched sequences and the GenBank accession number of our submitted sequences of 12 swamp eel specimens.

Among 12 samples, 8 samples showed 95-100\% homology with $M$. cuchia species that were already deposited in NCBI GenBank database. The studied mct3 (collected from Tangail region), mcs1, mcs 2 and mcs 3 (collected from Sylhet region) specimens showed 83\% homology with Ophisternon spp. Four (mct3, mcs1, mcs2 and mcs3) were matched 
with Ophisternon bengalense ANGBF45828-19 under BOLD private database whereas mct1, mct2, mcbo1, mcbo2, mcbo3, mcba1, mcba2 and mcba3 were matched with $M$. cuchia BOLD accession number AAF8878. Finally, among 12 specimens, eight samples showed their genetic identity with $M$. cuchia known as freshwater mud eel and four samples showed similarity with Ophisternon bengalense known as Bengal eel or Asian swamp eel.

Table 1. Length-Weight measurements of swamp eel specimens collected from four different regions.

\begin{tabular}{clcc}
\hline SI & $\begin{array}{l}\text { Collection } \\
\text { place }\end{array}$ & $\begin{array}{c}\text { T.L } \\
(\mathrm{cm})\end{array}$ & $\begin{array}{c}\text { Weight } \\
(\mathrm{gm})\end{array}$ \\
\hline $1-3$ & Tangail & 41 & 60 \\
& & 66 & 250 \\
& & 56.5 & 350 \\
$4-6$ & Bogura & 58.5 & 510 \\
& & 61 & 520 \\
& & 60 & 350 \\
$7-9$ & Bagerhat & 51 & 490 \\
& & 25 & 170 \\
& & 56 & 500 \\
$10-12$ & Sylhet & 45 & 250 \\
& & 56 & 430 \\
& & 53 & 360 \\
\hline
\end{tabular}

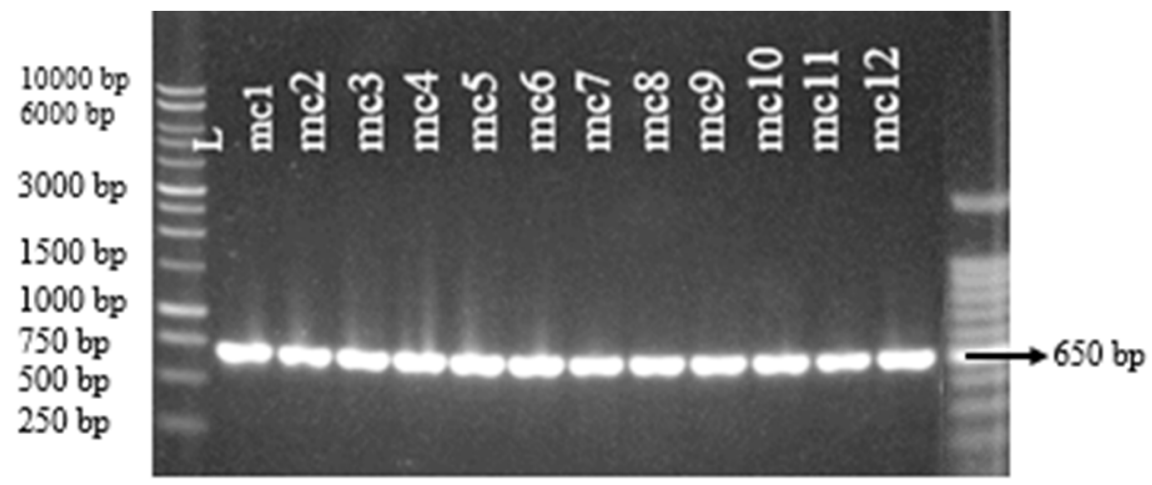

Fig. 1. PCR amplification of COI gene using FishF1 and FishR1 primers. L denotes 1 kb ladder. 
COI gene sequence of mct1, mcbo1, mcba1 were compared with available sequences from the GenBank database and it has been found that these specimens were M. cuchia. After comparing these sequences with M. cuchia NBFGR: MC8069B_FJ4595, 37 (6.7\%) out of 555 nucleotide bases found polymorphic (Fig. 2).

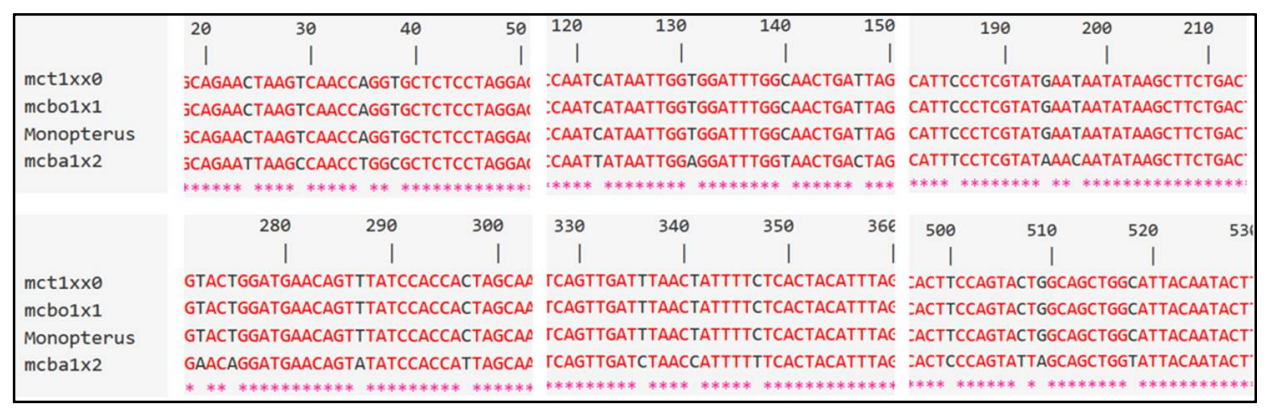

Fig. 2. Portion of Multiple Sequence Alignment (MSA) of COI gene fragment of swamp eel sample met1, mcbo1, mcba1 and $M$. cuchia_NBFGR_MC8069B_FJ4595. Black nucleotides among the red indicate polymorphic sites.

A comparison of COI sequence of mct $3, \operatorname{mcs} 1, \operatorname{mcs} 2$ and mcs 3 with available sequence from the GenBank database reflects that these specimens were under the genus Ophisternon. After comparing these sequences with $O$. bengalense_ANGBF45828-19, 74 (14.15\%) out of 523 nucleotide bases found polymorphic (Fig. 3).

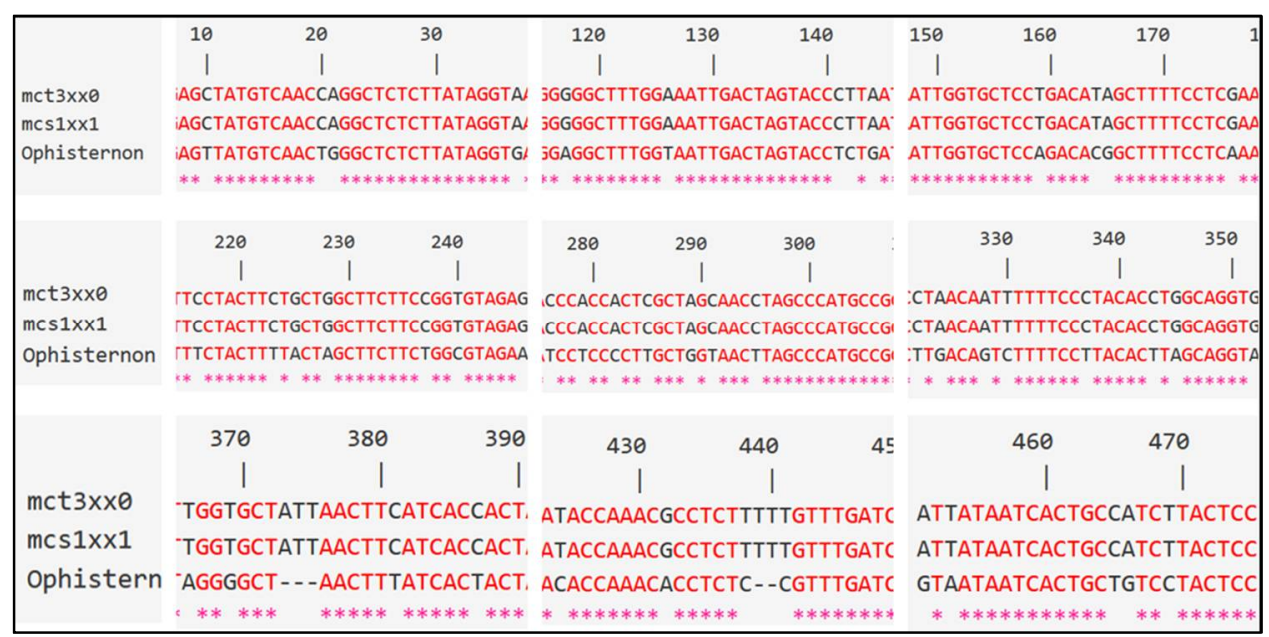

Fig. 3. Portion of Multiple Sequence Alignment (MSA) of COI gene fragment of swamp eel samples met3, mcs1 and $O$. bengalense_ANGBF45828-19. Black nucleotides among the red indicate polymorphic sites. 


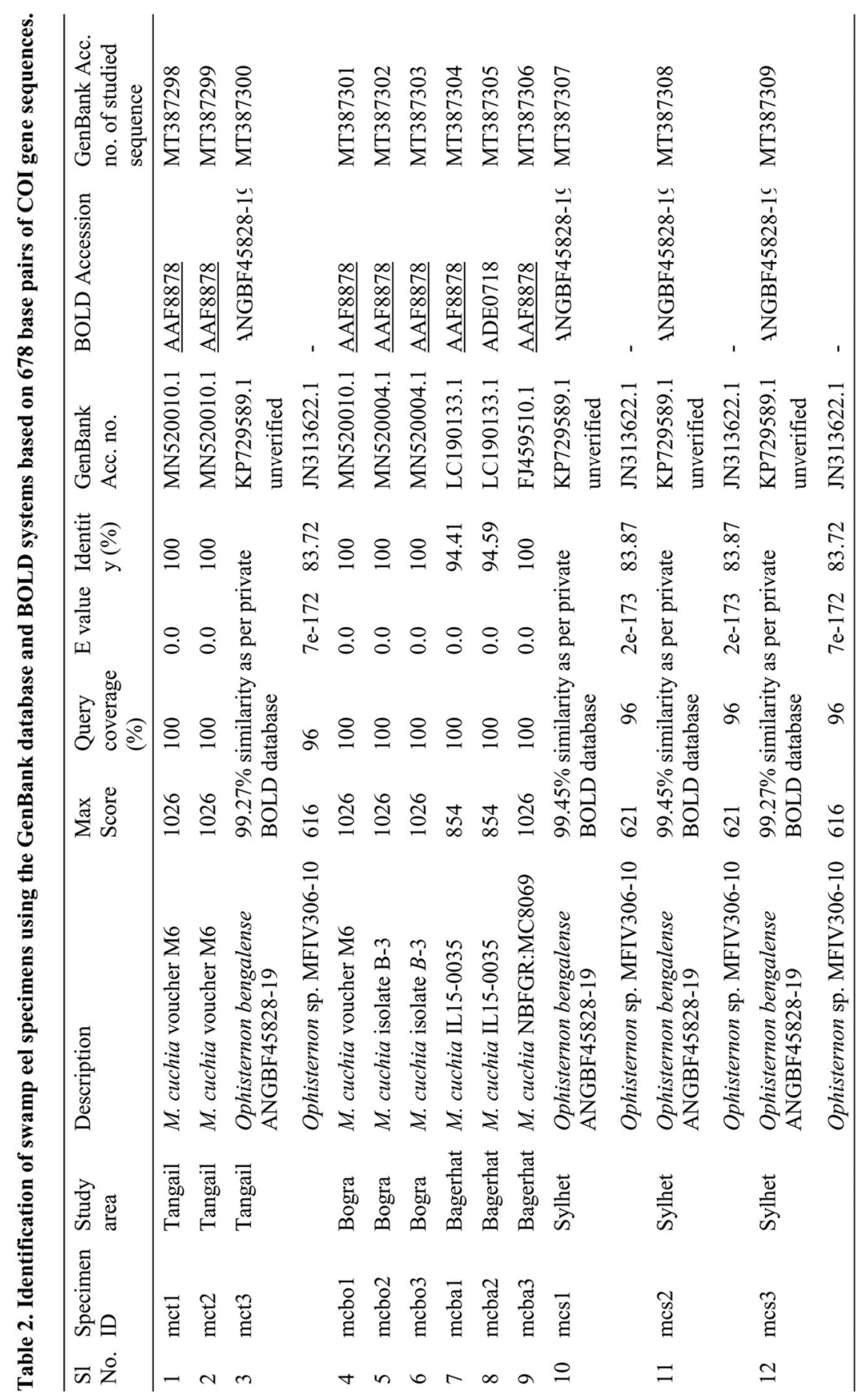


The phylogenetic tree (Fig. 4) indicates that mct1, mct2, mcbo1 are closely related to mcba3, mcbo2 and mcbo3 which confirming their similarity with the allocated species $M$. cuchia. On the other hand, the phylogenetic tree also supported the taxonomic position of mct3, mcs1, mcs 2 and mcs3 as similar with the species under the genus Ophisternon; moreover, it can be said that these specimens are close to the species Ophisternon bengalense, but may be another species of the genus Ophisternon that is still not available in the GenBank or BOLD public database.

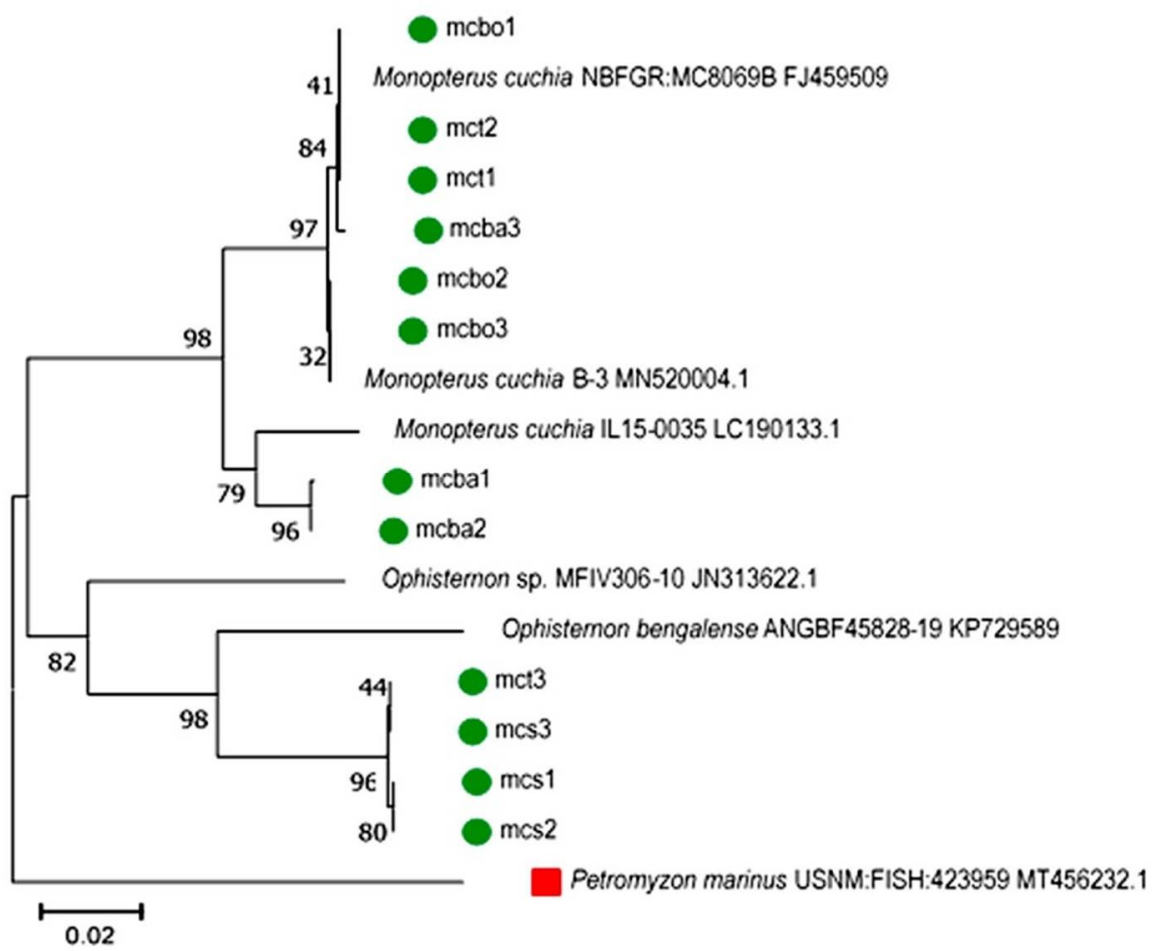

Fig. 4. Molecular Phylogenetic analysis by Neighbor-Joining method of studied 12 swamp eel sequences and downloaded 6 sequences from NCBI GenBank. Petromyzon marinus was used as an outgroup. The optimal tree with the sum of branch length $=0.36912245$ is shown. The analysis involved 18 nucleotide sequences. There were a total of 678 positions in the final dataset. Evolutionary analyses were conducted in MEGA X (Kumar et al. 2018).

RAPD based genetic diversity: DNA profiling and data scoring were studied separately for six primers that were used for RAPD analysis. The bands of six primers were seen in different levels of the length of DNA ranged from 250 to $1800 \mathrm{bp}$. A total of 192 bands, of which 35 were polymorphic with 17.88 average percentage of polymorphisms among 
species of swamp eel (Table 3). Primer OPH-04 gave the RAPD profile with the highest number of bands. The number and size of each unique band respective to each primer were shown in Table 3 and Fig. 5.

Table 3. Compilation of RAPD analysis data of swamp eel from four different locations of Bangladesh.

\begin{tabular}{lccccc}
\hline $\begin{array}{l}\text { Primer } \\
\text { code }\end{array}$ & $\begin{array}{c}\text { Size ranges } \\
(\mathrm{bp})\end{array}$ & $\begin{array}{c}\text { Total } \\
\text { bands }\end{array}$ & $\begin{array}{c}\text { Number of } \\
\text { polymorphic } \\
\text { bands }\end{array}$ & $\begin{array}{c}\text { Polymorphisms } \\
(\%)\end{array}$ & $\begin{array}{c}\text { Average \% } \\
\text { polymorphism }\end{array}$ \\
\hline OPA12 & $250-750$ & 20 & 03 & 15.00 & \\
OPY-07 & $375-1100$ & 25 & 05 & 20.00 & 17.88 \\
OPG-03 & $300-1400$ & 43 & 08 & 18.61 & \\
OPH-04 & $250-1800$ & 47 & 08 & 17.02 & 17.88 \\
UBC-04 & $700-1000$ & 12 & 02 & 16.67 & \\
OPC-05 & $450-1100$ & 45 & 09 & 20.00 & \\
\hline Grand total & & 192 & 35 & & \\
\hline
\end{tabular}

The value of pair-wise genetic distances was analyzed by using computer software "POPGEME 32" (version 1.31). The genetic distances ranged between 0.0000 and 1.6094 (Below diagonal of Table 4) among 12 specimens of swamp eel. The maximum genetic distance (1.6094) was observed among mcs3 and mcba2, while between mct1 and mct2, the minimum genetic distance was 0.000 .

After the analysis of RAPD fragments through computer software "POPGENE32" (version 1.31), the values of pair-wise genetic identity were ranged between 0.2000 and 1.000 (Above diagonal of Table 4). The highest genetic identity (1.000) was obtained between mct 1 and mct2, while the lowest one $(0.2000)$ was found between mcba2 and mcs3.

UPGMA based cluster analysis using linkage distance was done to reveal the phylogenetic relationships among twelve specimens of swamp eel genotypes examine under the current study (Fig. 6).

In the present study, UPGMA dendrogram showed that sample mct 1 and mct 2 were close to mcba3, whereas sample mcbo1, mcbo2 and mcbo3 were clustered together (Fig. 6). Specimen mcba1 and mcba2 were in the same cluster separated from other specimens. Sample mcs1, mct3, mcs 2 and mcs 3 formed a completely separate cluster away from 
others that is also supported by the DNA barcode data as these four specimens identified as Ophisternon spp.
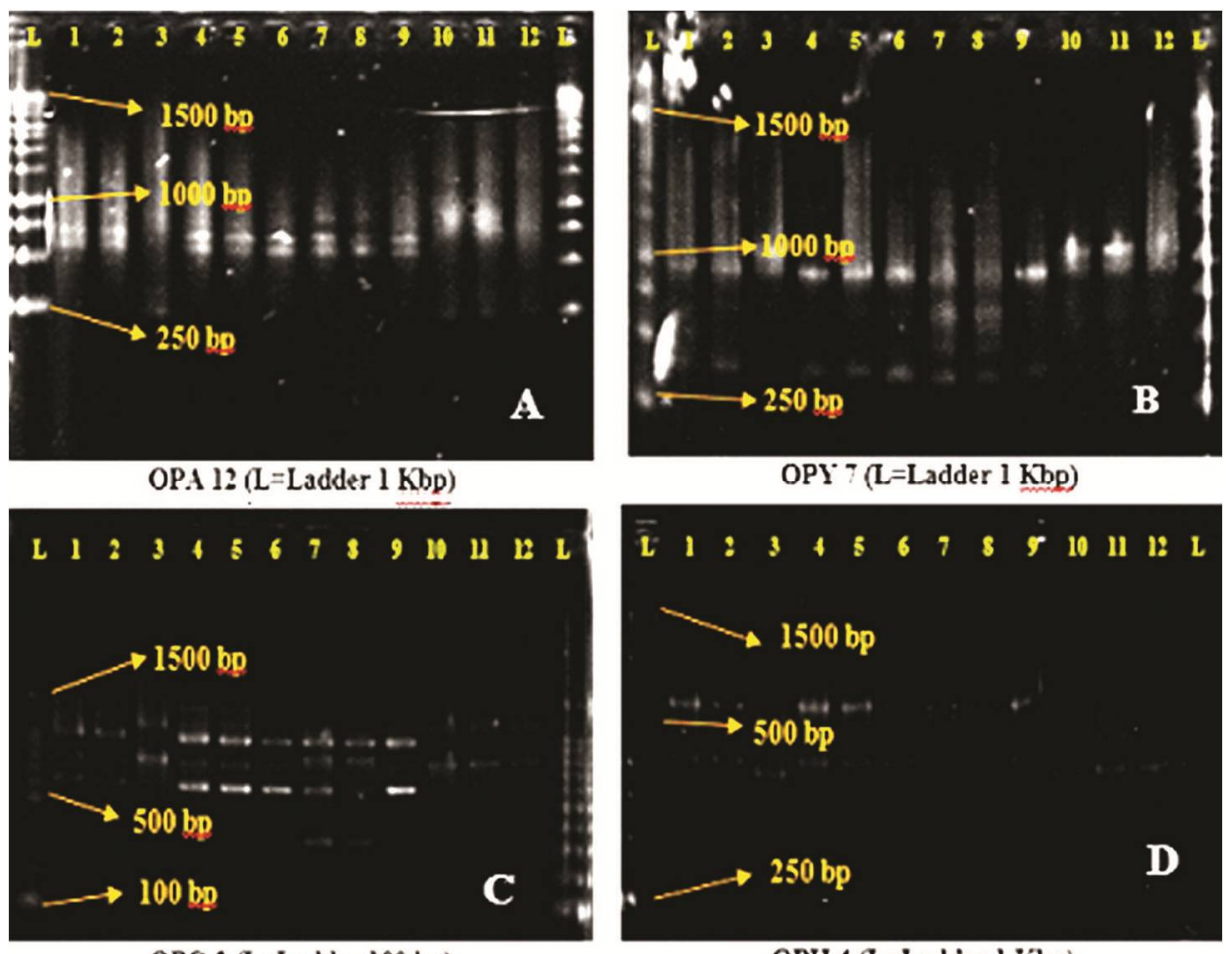

OPG 3 (L=Ladder $100 \mathrm{bp}$ )

$\mathrm{OPH} 4(\mathrm{~L}=\mathrm{L}$ adder $\mathrm{l} \mathrm{Kbp})$

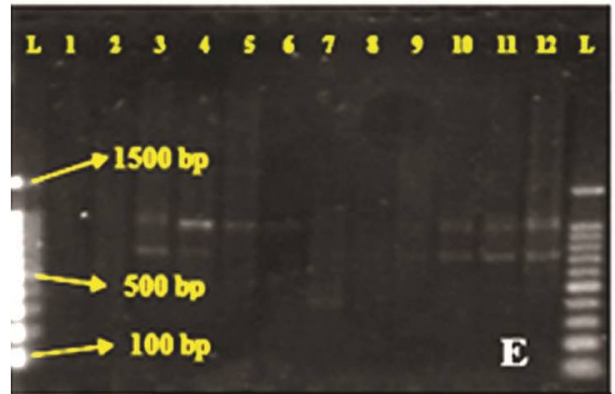

(BC $+(\mathrm{L}=\mathrm{L} \cdot \mathrm{sdd}+\mathrm{I}] \mathrm{l00} \mathrm{bp})$

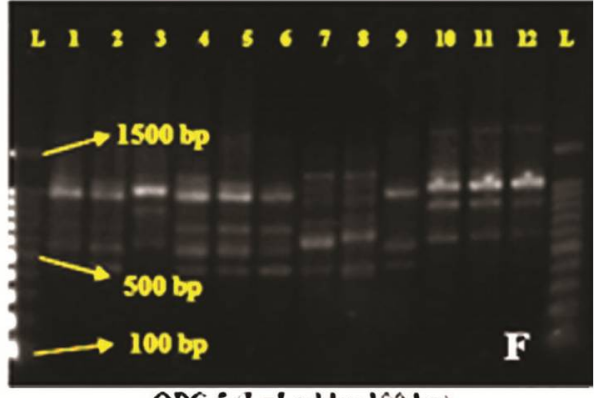

OPC $\leq$ L L-Ladder loObp)

Fig. 5. RAPD analysis with six primers of twelve swamp eel samples. (Primers; A. OPA-12, B. OPY-07, C. OPG-03, D. OPH-04, E. UBC-04, F.OPC-05, where 1- 3=Tangail, 46=Bogura, 7- 9= Bagerhat and 10-12=Sylhet samples in order). 


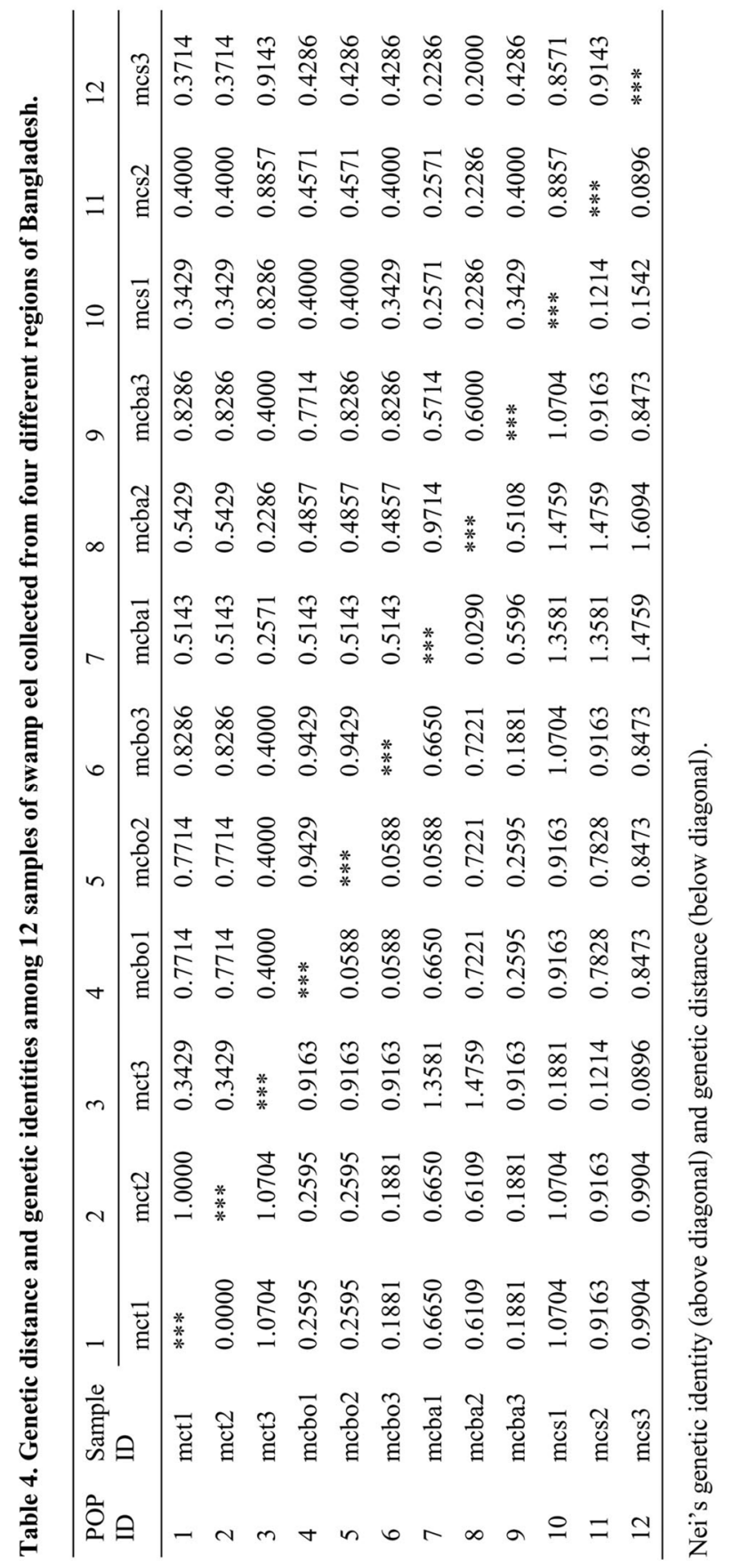




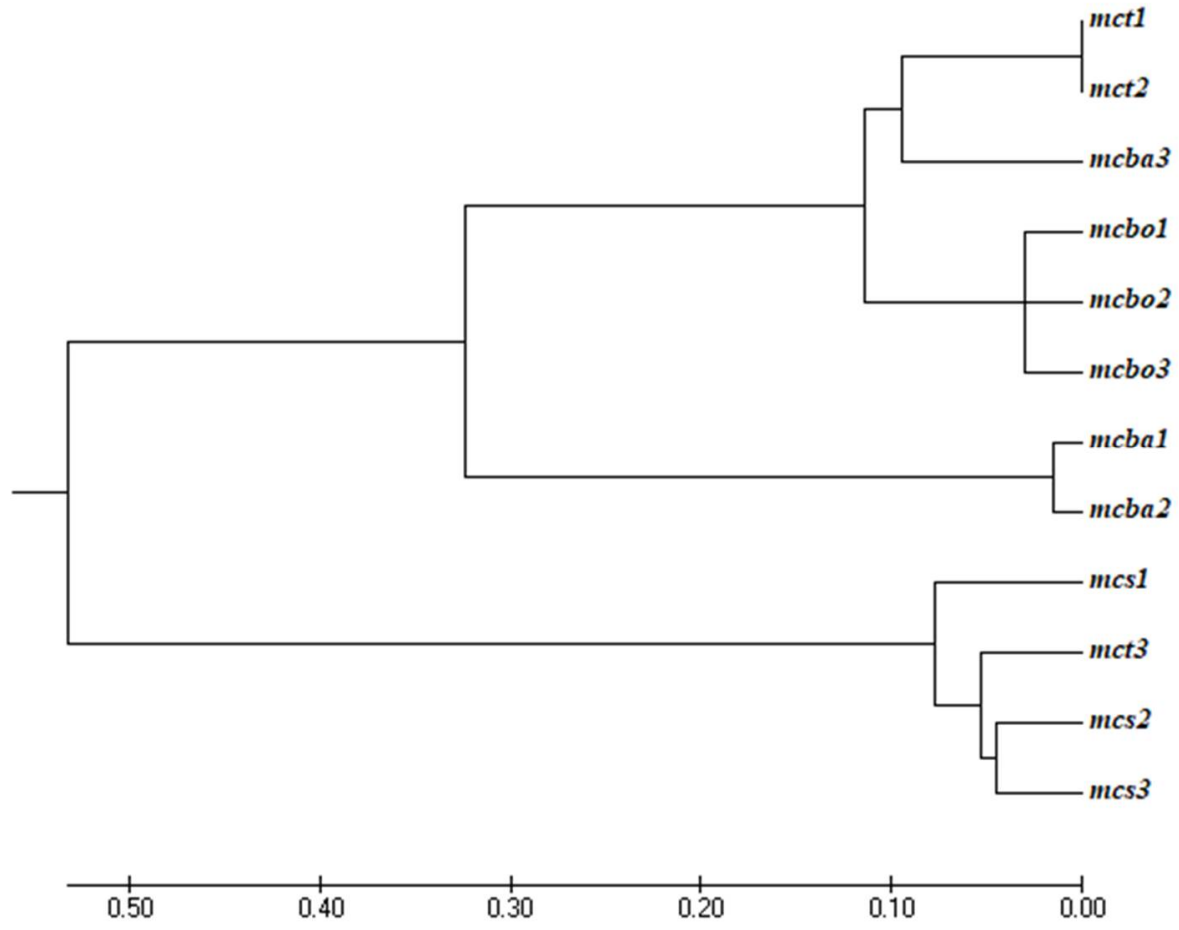

Fig. 6. UPGMA dendrogram based on RAPD analysis among 12 swamp eel samples. The dendrogram was constructed in MEGA7.

Bangladesh has vast water areas that are rich in fish and shellfish biodiversity (Rahman et al. 2016). Still many of our indigenous aquatic species are listed in the IUCN Red Book as endangered species. Monopterus cuchia and Ophisternon bengalense are red listed vulnerable species in Bangladesh (IUCN 2015). In the past, the identification of fish species was especially based on morpho-taxonomy (Kon et al. 2007). Expert taxonomists play an important role in the taxonomic classification of organisms and estimate species diversity, but this process is not enough to accurately identify the species. DNA barcoding provides rapid and accurate identification that can be used by the non-experts (Hebert et al. 2003). Lakra et al. (2016) worked on DNA barcoding of Indian freshwater fishes and observed the highest genetic distance (27.50\%) between Monopterus cuchia and Macrognathus pancalus, which belongs to the order of Synbranchiformes. Java and Dasgupta (2007) worked on the morphometry of M. cuchia from the New Alluvial Zone of West Bengal. They concluded that the morphometric characters of M. cuchia showed a positive increase with the increase in the length of the fish. Matsumoto et al. (2010) used 
mitochondrial DNA (mtDNA) sequencing to see the phylogenetic relationships and genetic diversity of $M$. albus. They found three genetically distinct clades based on geographical populations [China-Japan (Honshu + Kyushu), Ryukyu Islands, and Southeast Asia clades].

In this study, molecular identification of swamp eel species was performed by DNA barcoding. A total 12 samples were sequenced, among them eight samples were genetically identified as $M$. cuchia and four samples showed similarity with Ophisternon bengalense known as swamp mud eel. Four sequences viz. mct3, mcs1, mcs 2 and mcs3 could not be identified in the public BOLD species reference database. Steinke et al. (2009) found that analysis of COI gene from 391 species from 8 coral reef locations revealed $98 \%$ of these species exhibit distinct barcode clusters, allowing accurate identification.

In RAPD analyses specimens of swamp eel produced different banding pattern with six primer combinations. The average polymorphism was about $17.88 \%$ revealing a low range of polymorphisms among the two populations. Miah et al. $(2013,2016)$ used three RAPD primers to see the genetic diversity of freshwater mud eel, M. cuchia and found $100 \%$ intra-specific polymorphism among swamp eel. Yin et al. (2005) evaluated the genetic variation of the wild and cultured swamp eels M. albus using RAPD technique and found $44.79 \%$ and $36.5 \%$ polymorphism, respectively. Studies on RAPD fingerprinting of two eel-loaches, Pangio piperata and Pangio filinaris estimated 83\% and $60 \%$ polymorphism, respectively in 82 bands generated from five RAPD primers (Ruzainah et al. 2003). Wei et al. (2006) worked on five populations of rice field eel, $M$. albus in China mainland and found a low level of polymorphism (ranged from 29.51 to $66.39 \%)$. However, two other populations showed a high proportion of polymorphic loci $(82.79 \%)$.

The study was conducted on the genetic characterization of swamp eel of Bangladesh through DNA barcoding and RAPD techniques. The swamp eel can meet the increasing demand for animal source protein in Bangladesh and earn foreign currencies that can help our national economy. The information on DNA barcoding to identify freshwater mud eel can help to know the genetic diversity of them, ensure the reliability of the published taxonomic information, and initiate proper management programs to conserve this vulnerable species. The diversity of mud eel of Bangladesh can expand our export limit, which may help in employment generation in the production and marketing of fisheries and aquaculture sectors. 


\section{References}

Basagoudanavar, S.H., J.R. Rao, R.K. Singh and G. Butchaiah. 1998. Random amplification of polymorphic DNA fingerprinting of Trypanosoma evansi. Vet. Res. Commun. 23: 249-255.

Begum, N., M.M.H. Pramanik, M.G.S. Riar and Y. Mahmud. 2018. Effect of selected feeds, feeding frequency and density on growth and survival on mud eel Monopterus cuchia (Hamilton 1822) larvae. Int. J. Fish. Aquat. Stud. 6(4): 562-569.

DoF. 2016. National Fish Week 2016. Department of fisheries, Ministry of Fisheries and Livestock, Bangladesh. pp. 76.

Epifanio, J.M. 2003. Genetic variation: nuclear DNA. In: Brown B.L., Hallerman E.J., editors. Genetic Principles and Practices for Fisheries Scientists. American Fisheries Society; Bethesda, Maryland: 101-126

Hebert, P.D.N., A. Cywinska, S.L. Ball and J.R. Waard. 2003. Biological identifications through DNA barcodes. Proc. R. Soc. Lond. 270: 313-321.

IUCN Bangladesh. 2015. Red List of Bangladesh Volume 5: Freshwater Fishes. IUCN, International Union for Conservation of Nature, Bangladesh Country Office, Dhaka, Bangladesh, pp. 136.

Java, D. and M. Dasgupta. 2007. Morphometric study of the mud eel Monopterus cuchia (HAM.) From the new alluvial zone of West Bengal. Rec. Zool. Surv. India. 107(2): 21-30.

Kabir, M., M.S. Rahman, M. Begum and M.H. Faruque. 2017. Genetic diversity by RAPD in four populations of Rohu Labeo rohita. Croatian J. Fish. 75(1): 12-17.

Kon, T., T. Yoshino, T. Mukai and M. Nishida. 2007. DNA sequences identify numerous cryptic species of the vertebrate: A lesson from the gobioid fish Schindleria. Mol. Phylogenet. Evol. 44(1): 53-62.

Kumar S., G. Stecher, M. Li, C. Knyaz and K. Tamura. 2018. MEGA X: Molecular Evolutionary Genetics Analysis across computing platforms. Mol. Biol. Evol. 35: 1547-1549.

Lakra, W.S., M. Singh, M. Goswami, A. Gopalakrishnan, K.K. Lal, V. Mohindra, U.K. Sarkar, P.P. Punia, K.V. Singh, J.P. Bhatt and S. Ayyappan. 2016. DNA barcoding Indian freshwater fishes. Mitochondrial DNA. 27(6): 4510-4517.

Liu, Z., P. Li, B.J. Argue and R.A. Dunham. 1998. Inheritance of RAPD markers in channel catfish (Ictalurus punctatus), blue catfish (I. furcatus) and their backcross hybrids. Anim. Genet. 2(29): 58-62.

Menezes, G.M., M.F. Sigler, H.M. Silva and M.R. Pinho. 2006. Structure and zonation of demersal fish assemblages off the Azores archipelago (mid-Atlantic). Mar. Ecol. Prog. Ser. 324: 241260.

Miah, M.F., F. Haque, M.R. Mia, E. Jannat, H. Ali, M.M.A. Quddus and K. Ahmed. 2013. Molecular identification and sexual differentiation of freshwater mud eel (M. cuchia). Univers. J. Agric. Res. 1(3): 54-58.

Miah, M.F., K.M.A. Zinnah, M.J. Raihan, H. Ali and M.N. Naser. 2016. Genetic diversity based population study of freshwater mud eel (Monopterus cuchia) in Bangladesh. World. Acad. Sci. Eng. Technol. 10: 329-333.

Matsumoto, S., T. Kon, M. Yamaguchi, H. Takeshima, Y. Yamazaki, T. Mukai. and M. Nishida. 2010. Cryptic diversification of the swamp eel Monopterus albus in East and Southeast Asia, with special reference to the Ryukyuan populations. Ichthyol. Res. 57(1): 71-77.

Nasar, S.S.T. 1997. Backyard Eel Culture: International Institute of Rural Reconstruction, Silang, Cavite, Philippines. pp. 88. 
Palumbi, S.R. and F. Cipriano. 1998. Species identification using genetic tools: The value of nuclear and mitochondrial gene sequences in whale conservation. J. Hered. 89(5): 459-464.

Peninal, S., J. Subramanian, A. Elavarasi and M. Kalaiselvam. 2017. Genetic identification of marine eels through DNA barcoding from Parangipettai coastal waters. Genom. Data. 11: 8184.

Rahman, A.K.A. 2005. Freshwater fishes of Bangladesh, (2nd ed.). Zoological Society of Bangladesh. University of Dhaka. Dhaka, Bangladesh. pp. 65

Rahman, M.M., M.B. Rahman, E. Okazaki, and M.N.A. Rithu. 2016. Assessment of species specificity of fishing gears and fish diversity status in the Andharmanik river of coastal Bangladesh. J. Fish. Aquat. Sci. 11: 361-369.

Ratnasingham, S. and P.N.D. Hebert. 2007. BOLD: The barcode of life data system (www. Barcoding life. Org). Mol. Ecol. Notes. 7: 355-364.

Rosen, D.E. and P.H. Greemwood. 1976. A fourth neotropical species of synbranchid eel and the phylogeny and systematic of Synbranchiformes fishes. Bull. Am. Mus. Nat. Hist. 157: 5-69.

Roy, P., N. Lucky and M. Hossain. 2016. Morphological Characterization of Two Fresh Water Eels Monopterus cuchia (Hamilton, 1822) and Ophisternon bengalense (McClelland, 1844). J. Environ. Sci. Nat. Resour. 9(1): 127-137.

Ruzainah, A., M.N.S. Azizah, I. Patimah and A. Amirrudin. 2003. RAPD fingerprinting of the eelloaches Pangio filinaris and Pangio piperata: preliminary evaluation. Aquacult. Res. 34: 959965.

Saitou, N. and M. Nei. 1987. The neighbor-joining method: A new method for reconstructing phylogenetic trees. Mol. Biol. Evol. 4: 406-425.

Shafi, M. and M.M.A. Quddus. 1982. Bangladesher Matshyo Sampad. Bangla Academy, Dhaka. pp. 245-246.

Smith, P.J., D. Steinke, S.M. Mcveagh, A.L. Stewart, C.D. Struthers and C.D. Roberts. 2008. Molecular analysis of Southern Ocean skates (Bathyraja) reveals a new species of Antarctic skate. J. Fish Biol. 73: 1170-1182.

Steinke, D., T.S. Zemlak and P.D.N. Hebert. 2009. Barcoding Nemo: DNA-Based Identifications for the Ornamental Fish Trade. Plos One. 4(7): E6300.

Talwar, P.K. and A.G. Jhingran. 1991. Inland Fishes of India and adjacent countries. Oxford-IBH publishing Co. Pvt. Ltd. 2: 776-777.

Teske, P.R., M.I. Cherry and M.I.C.A. Matthee. 2003. Population genetics of the endangered Knysna seahorse Hippocampus capensis. Mol. Ecol. 12(7): 1703-1715.

Ward, R.D., T.S. Zemakak, B.H. Innes, P.R. Last and P.D.N. Homles. 2005. DNA barcoding Australia's fish species. Phil. Trans. R. Soc. B. 360: 1847-1857.

Wei, R.B., G.F. Qiu and R. Song. 2006. Genetic diversity of rice field eel (Monopterus albus) in China based on RAPD analysis. Asian Fish. Sci, 19: 61-68.

Wong, E.H.K. and R.H. Hanner. 2008. DNA barcoding detects market substitution in North American seafood. Food Res. Int. 41: 828-837.

Yin, S., J. Li, G. Zhou and Y. Liu. 2005. Population genetic structure of rice field eel (Monopterus albus) with RAPD markers. Chin. J. Appli. Environ. Biol. 11: 328-332. 